International Journal of Economics, Business and Accounting Research (IJEBAR)

Peer Reviewed - International Journal

Vol-4, Issue-2, 2020 (IJEBAR)

E-ISSN: 2614-1280 P-ISSN 2622-4771

https://jurnal.stie-aas.ac.id/index.php/IJEBAR

\title{
MANAGING WOMEN EMPOWERMENT THROUGH PARTICIPATION IN SUSTAINABLE TOURISM DEVELOPMENT IN KAMPONG PHLUK, SIEM REAP, CAMBODIA
}

\author{
Vicheth Nara ${ }^{1}$, Nico Irawan ${ }^{2}$ \\ International College, Rajamangala University of Technology Krungthep ${ }^{1,2}$ \\ Email: vichethnara168@hotmail.com \\ nico.i@mail.rmutk.ac.th
}

\begin{abstract}
Tourism has been one of important Cambodia's key economic growth drivers (OECD, 2018). After Khmer Rouge, most Cambodian women have become head of their families and indispensable part of the development in all sectors in Cambodia, including tourism. This study aims to explore how tourism influences on managing women empowerment and the participation of women in sustainable tourism development in Kampong Phluk community-based tourism site, Siem Reap, Cambodia. The qualitative descriptive approach with in-depth interviews, has been used for collecting data. The eighteen interviewees had at least 2 years' experience in managing and participating in community-based tourism, especially female members. The constant comparison analysis is used to analyse data collected from the interviewees. The result revealed that tourism truly brings many socio-economic benefits to the local community, especially female members of the community by empowering them economically, socially, psychologically, and politically. This study also found that women are the key contributors to the development of sustainable tourism in their community by participating in all activities regarding economic sustainability, socio-cultural sustainability, and environmental sustainability, by managing the benefits from tourism and distributing them fairly to all people in the community but minimizing the negative impacts on the community's natural resources plus preservation of the local culture.
\end{abstract}

Keywords: $\quad$ Community-Based Tourism, Sustainable Tourism Development, Women Empowerment, Women's Participation

\section{Introduction}

Tourism is one of Cambodia's key economic growth drivers and will remain an important part of the country's economy in the future (OECD, 2018). However, when it comes to economic growth, environmental degradation is unavoidable due to the increase of non-renewable resources consumption, air pollutant emission to the atmosphere, and deforestation, etc. Hence, the sustainable tourism development is needed for the long-term development of tourism in Cambodia, especially for managing how to apply in the community-based tourism site which is located in the rural area and has vulnerable people living in. Moreover, due to a large number of men death during Khmer Rouge that caused the demographic imbalance in Cambodia (McGrew, 1990), most of women have become head of their families and indispensable part of the development in all sectors in Cambodia, including the tourism sector. According to the speech of H.E. Thong Khon, the Minister of Tourism of Cambodia declared at a celebration of the 107th Anniversary of International Women's Day, 60 percent of the labor force in the tourism industry is dominated by women, including accommodation, food and beverage, and other entertainment services. This is a strong indication that women are indispensable stakeholders and key contributors to the economic development of Cambodia, (Khmer Times News, 2018). However, due to 
International Journal of Economics, Business and Accounting Research (IJEBAR)

Peer Reviewed - International Journal

Vol-4, Issue-2, 2020 (IJEBAR)

E-ISSN: 2614-1280 P-ISSN 2622-4771

https://jurnal.stie-aas.ac.id/index.php/IJEBAR

the traditionally based parental notion towards sons and daughters in the past, most of Cambodian girls have been kept away from education and became illiterate (ADB, 2015). As a result, the power of decision-making of women in the society during that time have been seized and handed over to men as decision makers.

On the contrary, due to the modernization and globalization in education in the last few decades, women's participation in society has been recognized globally. Although, the empowerment of women in society is still a challenge that must be solved. According to Women's Environment and Development Organization (2005), women have been absent in most of the decision-making, even the significant progress of women empowerment has been achieved at UN conferences throughout the 1990s. Also, the World Tourism Organization was used "Women empowerment in the Tourism Sector" as the main theme in the 63rd meeting of the UNWTO Regional Commission for the Americas. UNWTO's secretary-general suggested that the active participation of men and women is crucial to advance the women empowerment and help them become decision makers in the tourism sector (FTN NEWS, 2018). Due to the fact that most of the previous researches focused only on the empowerment of women in decision-making in the tourism sector, this research identified the influence of tourism on women empowerment and also their participation in sustainable tourism development in Kampong Phluk community-based tourism site where it was named as one of the twenty-two best tourist destinations in Cambodia for the year 2017-2018 by the ministry of tourism of Cambodia (RFA News, 2017).

\section{Limitations}

This study was conducted between February 10 until May 05, 2020, which took place in Kampong Phluk community-based tourism site, Siem Reap, Cambodia. By focusing only on tourism, specific in sustainable tourism development, this research will not attempt to discuss women empowerment in other sectors plus it will not study the barriers of empowering women in the community either. This research will study only the influence of tourism on managing to empower women in community-based tourism and their activities related to sustainable tourism development within their community.

\section{Literature Review}

Women empowerment has become a significant topic of discussion among country leaders and researchers since it is still an on-going issue in every country. Bayeh (2016), argued that the country which recognizes only men's participation and decision-making will not develop sustainably unless women are empowered, and gender equality is achieved first. In the tourism industry, the employment rate of women accounts for $46 \%$ compared with $43 \%$ employment in the economy (WTTC, 2019). Although, according to Skanavis and Sakellari (2008), gender inequality is still existing in tourism development. Thus, understanding citizen's perceptions of gender differences and improves knowledge, skills, and opportunities for women are the solutions to the problems.

\subsection{Sustainable Tourism Development}

The growth of tourism all over the world has created many issues for the environment that needs to be addressed for the achievement of sustainability for the long-term development of tourism and the country. Sustainable tourism is a new element in the tourism development concept with the purpose of reducing the negative effects of tourism and increase its positive advantages for the industry in order to maintain the country economic growth, the living condition of the locals, and excel other structure of development with maintaining natural resources which is vitally important for the lives of host communities (Muhanna, 2006). Tourism alone may not bring long-term economic benefits to society, especially for poor people, thus sustainable tourism development plans are needed as the contributor to reduce poverty (Harrison \& 
International Journal of Economics, Business and Accounting Research (IJEBAR)

Peer Reviewed - International Journal

Vol-4, Issue-2, 2020 (IJEBAR)

E-ISSN: 2614-1280 P-ISSN 2622-4771

https://jurnal.stie-aas.ac.id/index.php/IJEBAR

Schipani, 2007). Additionally, sustainable tourism plays an important role as a key actor which generates income to the local communities and other businesses related to tourism. There are many evidences have been shown that any tourist destinations that reduce environmental effects have generated more profit, become more competitive, increased value, and become more sustainable (Hardy \& Beeton, 2001).

\subsection{Community-Based Tourism and Women's Participation}

According to Kunjurman and Hussin (2016), they found that ecotourism activities in the community have influenced the local community participation, especially women, which then have empowered them. Moreover, the participation of outside stakeholders also plays a key role in developing the community sustainably, they added. In addition to this, the participation of women in their community plays an essential role in fulfilling their family's and community's economy through owning and managing homestays, preparing food for tourists, and developing agro-tourism-based village area within the community (Widiastuti et al., 2019). Furthermore, the participation of women in their community-based tourism site through various activities, such as making crafts, showing cultural dances, leading local-tour within the community, and managing homestays have given them the opportunity to partake equally to men in the benefit from the tourism sector and alleviate from the poverty (Randell \& Chapman, 2011). Additionally, for the community-based tourism site, which is located in the fishing villages, fishing can be considered as the main source of revenue for the community. However, due to the demand of physical strength of laborers for working in the fishing lot and in the forest, women were considered unsuitable for these kinds of jobs, thus working with tourists such as, making crafts, selling foods, paddling boat for tourists, and being floating gardeners are the most suitable jobs for them due to the fact that those jobs are matched with their physical strength, allow them to work close to their home, generate more income for their family, and avoid them migrating to the cities for the purpose of finding a good job (Dowley, 2007).

\subsection{Women empowerment in Tourism Industry}

According to Scheyvens (1999), she developed an empowerment framework consist of four dimensions which can be used as the tool for analyzing the influence of tourism on the local community. This framework showed that tourism activities influenced community participation, including women, and empowered them economically, socially, psychologically, and politically. Women empowerment in the community-based tourism will help to increase women's self-esteem and status within their community and also could promote sustainable development, if the policymaker includes a gender analysis assessment to the development process of the tourist destination (Dunn, 2007). Even though, there are many gender inequalities in the tourism sector, yet tourism has enough potential as the vehicle to empower women by providing them better opportunities as the employees, entrepreneurs, and leaders than other sectors of the economy (Nichola, 2011).

\section{Methodology}

Women empowerment has been considered as a sensitive topic in society (Hazel et al., 2017) plus sustainable tourism development has been aroused the stakeholder attention in the tourism industry (Jianwei et al., 2018). This research focuses on the women perspective in the community about managing the influences of tourism on their empowerment, and their experiences of participation in sustainable tourism development processes within their community. Using a qualitative approach with in-depth interviews for collecting data from eighteen interviewees, who had at least 2 years' experience in managing and participating in community-based tourism, especially female members. The qualitative method allows the interviewees to explain their ideas in detail that provide a richer understanding of the respondents' experiences. Purposive sampling and snowball sampling techniques are used to select the 
International Journal of Economics, Business and Accounting Research (IJEBAR)

Peer Reviewed - International Journal

Vol-4, Issue-2, 2020 (IJEBAR)

E-ISSN: 2614-1280 P-ISSN 2622-4771

https://jurnal.stie-aas.ac.id/index.php/IJEBAR

interviewees for the study. Firstly, the chief of the community-based tourism site is selected for the interview. Then, the community chief recommended another person for the interview, and repeated process of referrals. The interview was conducted in Khmer language plus translation was checked by other researchers. Kampong Phluk community was selected because of its well-known reputation among all community-based tourism site in Tonle sap area and most of the tourism activities were run by locals, especially women.

\section{Results and Discussions}

\subsection{The Role of Community in Managing Women Empowerment}

Kampong Phluk community-based tourism site is one of the most well-known tourist attractions among local and international tourists due to its beautiful scenery of flooded forests, diversity of wild birds, and unique way of life of the local people. The most attractive tourism activity in the community is travelling by small boat with women paddlers to see wild birds and flooded forests in Tonle Sap lake. Upon seeing that women's participation in tourism is attractive to tourists, the community has worked with many NGOs, including FAO, World Vision, and UNDP to provide vocational and language training to women, ensuring that they are educated and able to use it to earn additional income for their family. Moreover, the community has encouraged poor families to send their children to school, especially their daughters, by using the community's funds to support them at least until their children finish primary school. Finally, the community has worked with the ministry of women's affairs of Cambodia in planning and promoting women by giving them more opportunities to participate in community decision-making and management.

\subsection{The Influence of Tourism on Women Empowerment in Kampong Phluk Community-Based Tourism Site}

After Kampong Phluk community-based tourism sites became more and more popular among tourists, women in the community who were previously unemployed or were just housewives could earn additional income for supporting their family and even contribute to the development of the community. In addition to this, all interviewees agreed that tourism has helped transform the image of Kampong Phluk community as well as enhance the role of women in community development.

\subsection{Sign of Economic Empowerment}

Economic benefits from participating in tourism activities, according to the chief of Kampong Phluk commune emphasized that most women in the community can make more money than their husbands who are the fishermen. After the popularity of Kampong Phluk community-based tourism site has risen among local and international tourists in the last few years, female members of community have earned additional income through selling souvenirs, puddling boat for tourists, running restaurants, and homestays. This additional income helps women in their household's decision-making process, what they previously did not have at all because source of income for supporting whole family was from their husbands. Moreover, after most women earned more incomes than their husbands as participating in tourism activities, they have gained more respect from their husbands and the contempt on them has been alleviated as well. All interviewees stated:

"most of the income from tourism activities have been used for repairing their houses, investing in their children's education, buying stuff, paying off their debt, and saving for unpredictable events".

\subsection{Sign of Social Empowerment}


International Journal of Economics, Business and Accounting Research (IJEBAR)

Peer Reviewed - International Journal

Vol-4, Issue-2, 2020 (IJEBAR)

E-ISSN: 2614-1280 P-ISSN 2622-4771

https://jurnal.stie-aas.ac.id/index.php/IJEBAR

Women are playing a very dynamic role in development of Kampong Phluk community. As a result, their participation, dedication, and achievements in the community development have been recognized and appreciated by members of the community, which is led to social cohesion within their community. In addition to this, one part of the revenue from tourism activities in the community including entrance and boat fees have been deducted for community development purposes, such as helping poor, providing salary to community's securities, maintaining community hygiene, and enhancing the livelihood in community. This shows how strong tourism influenced social empowerment of women in the community that cannot be overlooked.

\subsection{Sign of Psychological Empowerment}

This research found that the self-esteem of women in Kampong Phluk community-based tourism site has been gained through their participation in tourism activities. After women in the community had the opportunity to earn income on their own, most of them said:

"they are proud of themselves that their presence has contributed to the development of their family and community as a whole".

Furthermore, they also emphasized that their self-esteem was improved even more due to the recognition of outsiders, especially tourists regarding their community reputation, local cultures, and other natural attractions within the community.

\subsection{Sign of Political Empowerment}

In Kampong Phluk community-based tourism site, women are indispensable actors in decision-making process due to their top positions and numbers in the community management structure, such as the vice president of the community, member of the commune council, and commune officers. According to the president of Kampong Phluk community-based tourism site stated:

"all members in the community, especially women members who made up a large proportion of the total permanent members, have enough right to express their feelings and opinions regarding the community's decisions plus they can criticize and request changes to the government's decision as well, in case they feel that the decision will not bring enough benefits for the community. For instance, in 2015, when the government decided to hand over all control of the natural resources within Kampong Phluk area to the private company, people in the community began to protest for their right to claim back their resources and asked for taking control by themselves. Finally, the government agreed to return the surrounding area to the community control, and then those areas have been used as tourist destinations for attracting both local and international tourists".

This is a strong indication that political empowerment among the community members, especially female members has been realized.

\subsection{Participation of Women in Sustainable Tourism Development}

There are three key components in sustainable development: economic sustainability, socio-cultural sustainability, and environmental sustainability (UNWTO, 2012). Hence truly sustainable tourism should have those three components too. Based on interviewees, it was revealed that women play a vital role in the development of the community and also engaged in all activities regarding sustainable tourism development.

\subsection{Women's Participation in Economic Sustainability}

Women's participation in Kampong Phluk community plays a key role in fulfilling and maintaining the community's economy by creating direct and indirect jobs for other villagers and generating revenue for 
International Journal of Economics, Business and Accounting Research (IJEBAR)

Peer Reviewed - International Journal

Vol-4, Issue-2, 2020 (IJEBAR)

E-ISSN: 2614-1280 P-ISSN 2622-4771

https://jurnal.stie-aas.ac.id/index.php/IJEBAR

the whole community. Most of restaurants and souvenir shops within community are owned and managed by women. These businesses have created both direct and indirect employments for other community members, such as waiters, souvenir sellers, cooks, handicraft makers, and local fresh food suppliers. In addition, part of revenue from boat rental services and the homestay program, which is owned or managed by women, has been deducted and used for community development purposes.

\subsection{Women's Participation in Socio-Cultural Sustainability}

Women are key contributors to the success of Kampong Phluk community-based tourism by playing as marketers in demonstrating, distributing, and promoting the unique cultures of the community to tourists. Through these activities, the pride of local people toward their cultures has been enhanced which led to cultural preservation within the community. Additionally, these women have been known as the cultural preservers of community by maintaining the way of creating crafts, such as hammock, fishing net, Khmer scarf, and other handicrafts which they learned from their ancestors and are passing on the knowledge to their descendants with purpose of preventing it from future lost. More importantly, women are the indispensable members of decision-making in the community, especially for those things, which pertain to the benefits of the entire community.

\subsection{Women's Participation in Environmental Sustainability}

Kampong Phluk community-based tourism site has become well-known among local and international tourists due to its attractive natural resources, such as flooded forests, wildlife, and sunset sightseeing. Women play a key role in conserving the environment within the community by protecting flooded forests plus wildlife from illegal logging and hunting by some greedy people. Moreover, female community members, who are the boat peddlers, have taken turns collecting garbage from their fishing village and flooded forests to ensure that the water is always clean and safe for welcoming tourists. Besides, these women are participating in the planning process of protecting and stopping illegal fishing within the community area to maintain sustainable fish populations for people in the community daily consumption and for tourism purposes.

\section{Conclusion}

Tourism is an industry that develops local economics of the world. There are many socio-economic benefits that tourism has brought to the local community, especially women members of the community, including empowering them economically, socially, psychologically, and politically, as example of Kampong Phluk community-based tourism site that has already been discussed in this research. Additionally, this study also found that the Scheyvens's empowerment framework is applicable in the real-life situation of the community-based tourism site. Additionally, the result of this study shown that women are the key contributors to the development of sustainable tourism in their community by participating in all activities regarding economic sustainability, socio-cultural sustainability. These women also managed environmental sustainability, by ensuring that the benefits from tourism will be distributed fairly among all people in the community but minimizing the negative impacts on the community's natural resources plus preservation of the local culture. Even though, women in Kampong Phluk community are considered as the key actors in the development of the community, yet the number of women at the political level is still limited due to lack of knowledgeable women among community members. Hence, facilitating and promoting education and healthcare for women in the community is necessary. Then they can be better managers at grassroots level. 
International Journal of Economics, Business and Accounting Research (IJEBAR)

Peer Reviewed - International Journal

Vol-4, Issue-2, 2020 (IJEBAR)

E-ISSN: 2614-1280 P-ISSN 2622-4771

https://jurnal.stie-aas.ac.id/index.php/IJEBAR

References

Asian Development Bank, (2015). Promoting Women Empowerment Economic in Cambodia. Manila. Retrieved from https://www.adb.org/sites/default/files/publication/ 156499/promoting-womenseconomic-empowerment.pdf

Bayeh, E. (2016). The role of empowering women and achieving gender equality to the sustainable development of Ethiopia. Pacific Science Review B: Humanities and Social Science, 2(1), 38

Dowley, A. (2007). How Do Women in Prek Toal Village (Tonle Sap Biosphere Reserve, Cambodia) Participate in and Benefit from Ecotourism? Independent Study Project (ISP) Collection. 208.

Dunn, S. (2007). Toward empowerment: Women and community-based tourism in Thailand. University of Oregon.

FTN NEWS (2018, April 17). Women empowerment in the Tourism Sector. Retrieved March 10, 2020, from https://ftnnews.com/mice/34079-women-s-empowerment-in-the-tourism-sector

Hardy, A.L, \& Beeton, R.J.S. (2001). Sustainable tourism as maintainable tourism: Managing resources for more than average outcomes. Journal of Sustainable Tourism, 9(3), 168-192.

Harrison, D., \& Schipani, S. (2007). Lao tourism and poverty alleviation: Community-based tourism and the private sector. Current Issues in Tourism, 10(2-3), 194-230.

International Food Policy Research Institute (IFPRI). (2016). Using Cognitive Interviewing to Improve the Women Empowerment in Agriculture Index Survey Instruments: Evidence from Bangladesh and Uganda.

Jianwei, Q., Huawen, S. \& Rob, L. (2018). Research in sustainable tourism: A longitudinal study of articles between 2008 and 2017. Sustainability 2018, 10(3), 590

Kunjurman, V. \& Hussin, R., (2016). Women Participation in Ecotourism Development: Are They Empowered? World Applied Sciences Journal, 34(12),1652-1658

Malapit, H.J, Sproule, K, \& Kovarik, C. (2017). Using cognitive interviewing to improve the Women's Empowerment in Agriculture Index survey instruments: Evidence from Bangladesh and Uganda. Journal of Gender, Agriculture and Food Security, 2(2), 1-22.

Muhanna, E. (2006). Sustainable Tourism Development and Environment Management for Developing Countries. Problems and Perspectives in Management 4 (2), 14-30.

Nichola, A. R. (2011). "Tourism" a Vehicle for Women empowerment: Prospect and Challenges.

Organisation for Economic Co-operation and Development (OECD). Economic outlook for Southeast Asia, China and India 2019: Toward smart urban transportation. Retrieved March 14, 2020, from http://www.oecd.org/dev/asia-pacific/saeo-2019-Cambodia.pdf

Randell, S. K. \& Chapman, M. J., (2011). Women empowerment through Community-based Tourism and Cultural Exchanges. Centre for Gender, Culture and Development Research Report 7.

RFA News (2017, December 05), Twenty-two tourist destinations were designated as the best tourist destinations for 2017-2018. Retrieved March 10, 2020, from https://www.rfa.org/khmer/news/social-economy/22locations-to-be-tourismsite-for-2017-201812052017080411.html?

Scheyvens, R., 1999. Ecotourism and the empowerment of local communities. Tourism Management, 20(2): 245-249.

Skanavis, C., \& Sakellari, M., (2008). Gender and sustainable tourism: Women's participation in the environmental decision-making process. European Journal Tourism Research, 1(2), 78-93.

World Tourism Organization (UNWTO) (2012, June 22). Tourism can contribute to the three pillars of sustainability. Retrieved April 24, 2020, from https://www.unwto.org/archive/global/pressrelease/2012-06-22/tourism-can-contribute-three-pillars-sustainability

International Journal of Economics, Business and Accounting Research (IJEBAR)

Page 268 
International Journal of Economics, Business and Accounting Research (IJEBAR)

Peer Reviewed - International Journal

Vol-4, Issue-2, 2020 (IJEBAR)

E-ISSN: 2614-1280 P-ISSN 2622-4771

https://jurnal.stie-aas.ac.id/index.php/IJEBAR

Widiastuti, T., Mihardja, E.J., \& Agustini, P.M., (2019). Women's participation on tourism villages' management in the Dieng Pandawa Tourism awareness group. ASEAN Journal of Community Engagement, 3(1), 122-138

Women's Environment and Development Organization (WEDO). (2005). Beijing Betrayed, Women Worldwide Report that Governments Have Failed To Turn the Platform into Action.

World Travel \& Tourism Council. Travel and Tourism: Driving Women's Success March 2019. Retrieved March 11, 2020, from https://www.wttc.org/economic-impact/social-impact/driving-womenssuccess/ 